\title{
Correction to: Numerical solution to the telegraph equation via the geometric moving Kriging meshfree method
}

\author{
M.S. Hashemi ${ }^{\mathrm{a}}$
}

Department of Mathematics, Basic Science Faculty, University of Bonab, P.O. Box 55517-61167, Bonab, Iran

Original article: Eur. Phys. J. Plus (2019) 134: 381, https://doi.org/10.1140/epjp/i2019-12741-8

Received: 9 October 2019

Published online: 25 October 2019

(C) Società Italiana di Fisica / Springer-Verlag GmbH Germany, part of Springer Nature, 2019

After publication, the author realized that the acknowledgment section was incorrect. Here is the correct version.

The author would like to thank the referees for very useful comments and remarks. This work was supported by a research grant from the University of Bonab [97/I/ER/205].

a e-mail: hashemi_math396@yahoo.com 